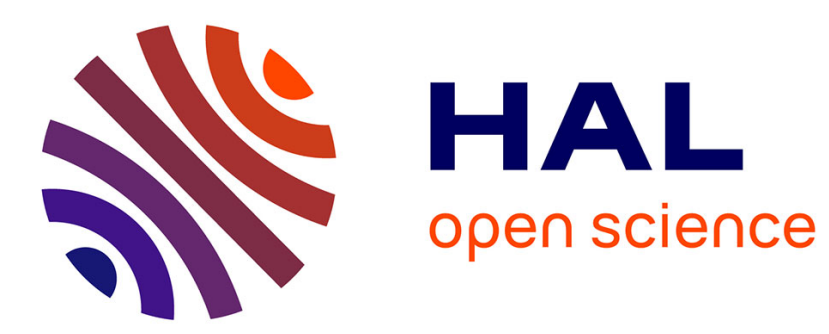

\title{
Emerging Patterns of Governance in the English Regions: The Role of Regional Assemblies
}

\author{
Graham Ronald Pearce, Sarah Ayres
}

\section{To cite this version:}

Graham Ronald Pearce, Sarah Ayres. Emerging Patterns of Governance in the English Regions: The Role of Regional Assemblies. Regional Studies, 2007, 41 (05), pp.699-712. 10.1080/00343400600929044 . hal-00514633

\section{HAL Id: hal-00514633 \\ https://hal.science/hal-00514633}

Submitted on 3 Sep 2010

HAL is a multi-disciplinary open access archive for the deposit and dissemination of scientific research documents, whether they are published or not. The documents may come from teaching and research institutions in France or abroad, or from public or private research centers.
L'archive ouverte pluridisciplinaire HAL, est destinée au dépôt et à la diffusion de documents scientifiques de niveau recherche, publiés ou non, émanant des établissements d'enseignement et de recherche français ou étrangers, des laboratoires publics ou privés. 


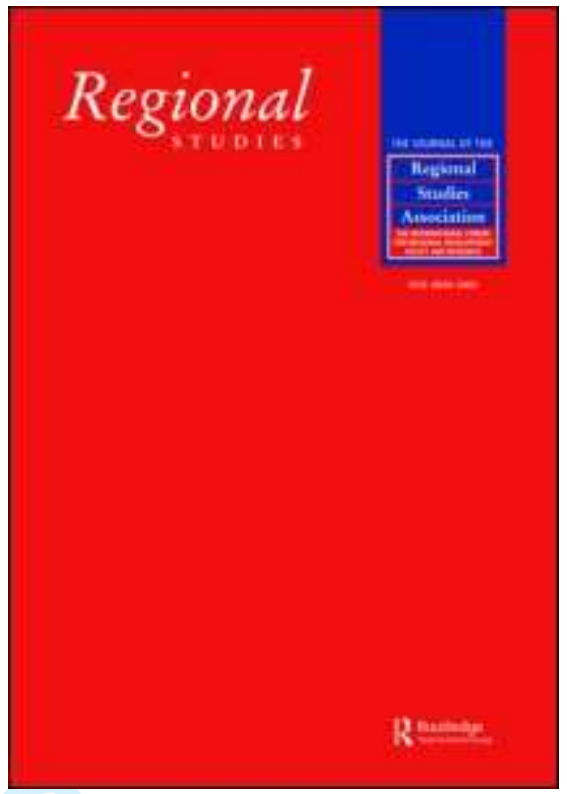

\section{Emerging Patterns of Governance in the English Regions: The Role of Regional Assemblies}

\begin{tabular}{|r|l|}
\hline Journal: & Regional Studies \\
\hline Manuscript ID: & CRES-2005-0026.R2 \\
\hline Manuscript Type: & Policy Debates \\
\hline JEL codes: & $\begin{array}{l}\text { D73 - Bureaucracy; Public Admin. Processes; Corruption < D7 - } \\
\text { Analysis of Collective Decision-Making < D - Microeconomics, H77 - } \\
\text { Intergovernmental Relations|Federalism < H7 - State and Local } \\
\text { Government|Intergovernmental Relations < H - Public Economics, } \\
\text { H10 - General < H1 - Structure and Scope of Government < H - } \\
\text { Public Economics, R58 - Regional Development Policy < R5 - } \\
\text { Regional Government Analysis < R - Urban, Rural, and Regional } \\
\text { Economics }\end{array}$ \\
\hline Keywords: & $\begin{array}{l}\text { English regional government , Devolution, Multi-level working, } \\
\text { regional assemblies }\end{array}$ \\
\hline
\end{tabular}

\section{SCHOLARONE Manuscripts}




\section{Emerging Patterns of Governance in the English Regions: The Role of Regional Assemblies GRAHAM PEARCE* and SARAH AYRES+ \\ * Aston Business School, Aston University, Birmingham, B4 7ET, UK. \\ Email: g.r.a.pearce@aston.ac.uk \\ + School for Policy Studies, University of Bristol, Bristol, BS8 1TZ, UK \\ Email:sarah.ayres@bristol.ac.uk}

The case for elected English regional government outside London has lost momentum, but the machinery of regional governance continues to expand. This article explores the significance of this process through an examination of the evolution of Regional Assemblies. Each has progressed differently, but all Assemblies lack political legitimacy and resources and have struggled to mobilize influence in Whitehall and their regions. Although contributing to greater coherence in regional governance, their future is uncertain and there is a need to systematically assess what tasks Assemblies should perform, and why, and the resources required for their delivery.

English regional government Devolution $\quad$ Regional Assemblies

Multi-level working

JEL classification: D7, D73, H77, R5, R58

\section{INTRODUCTION}

By contrast to the constitutional changes introduced in the Celtic nations and Greater London, the Labour Government has adopted more tentative reforms in the eight English regions based on administrative decentralization. During its first term, Regional Development Agencies (RDAs) were launched to prepare and deliver regional economic strategies (RESs) and Whitehall's representatives in the regions, the Government's 
Regional Offices (GOs), were bolstered to assist in coordinating national policies at regional and local levels. Voluntary Regional Chambers (later retitled Assemblies) were also introduced, comprising a mixture of local authority members and representatives of regional economic and social interests. They were conceived as transitional bodies in advance of the formation of elected Assemblies.

The 2002 White Paper, Your Region, Your Choice: Revitalizing the English Regions set out proposals to enhance the powers of the GOs, Assemblies and RDAs (the 'regional troika'), with the aim of improving decision-making, strategy co-ordination and delivery. Elected Assemblies would also be established in those regions where there was evidence of public support, expressed through referendums (CABINET OFFICE and DTLR, 2002). In the first referendum held in November 2004 in the North East, however, an overwhelming majority voted against the creation of an elected body. "A skilful 'No' campaign and a pervasive antipathy to the prospect of 'more politicians', that reflected national not regional factors, swamped any pro-elected assembly arguments" (JEFFERY, 2006, p. 67). More fundamentally, the national debate about regional government revealed the weakness or absence of any sense of public identity with the regions and opposition to an elected regional tier among most local authorities. The outcome was to eliminate the prospect of elected regional government outside London and to refocus attention on the roles of the existing Assemblies.

Originally designated in the 1998 Regional Development Agencies Act, the Assemblies' functions were ill defined, although the Act confirmed that they should hold RDAs accountable for their RESs. More substantive advice on their scrutiny role was offered in Strengthening Regional Accountability. Assemblies were urged to establish 'a stronger analytical or research capacity to monitor and evaluate the RDAs' plans' and ensure that their 'strategies and activities fit in with the wider framework of strategies across the 
region' (DETR, 2001, p. 6). Planning: Delivering a Fundamental Change (DTLR, 2001) marked a further step in the Assemblies' evolution by proposing that responsibility for preparing Regional Planning Guidance (RPG) should be transferred from regional local government associations (LGAs) to bodies more inclusive of regional interests. The implication was clear and the English Regions' White Paper confirmed that Assemblies should become Regional Planning Bodies (RPBs). In 2004 Assemblies also become responsible for preparing statutory Regional Spatial Strategies (RSSs), which replace RPG and are intended to be integrated more fully with other regional strategies (ODPM, 2004a). Indeed, the White Paper confirmed that Assemblies should engage in and contribute to policy work in other areas, play an active role in coordinating the multiplicity of regional strategies and work more closely with the GOs and other government bodies operating in the regions. The Assemblies' wider role in representing their regions and promoting regional priorities in Whitehall and Brussels was also acknowledged.

Alongside the GOs and RDAs, Assemblies are increasingly expected to act as a 'third force' in the regions. Rather than relying on traditional hierarchies to secure their objectives, they must engage in partnerships with representative or interest organizations to influence the preparation and delivery of a wide range of regional strategies. They are also expected to participate in the vertical or multi-level networks that connect EU, national and sub-national government. The designation of Assemblies as 'voices' for their regions can be seen, therefore, as an opportunity to open up new political spaces for the articulation of regional priorities and visions.

These developments can be regarded as evidence of the emergence of a less hierarchical, more fluid, networked and multi-level form of governance, in which collaboration and partnership working increasingly defines the contexts within which regional policies are formulated and delivered (BOGDANOR, 2005; BACHE and FlindERS, 2004; HAUGHTON and 
Counsell, 2004; RhODES, 1997). A more circumspect view, however, is that although Whitehall may have relinquished direct control over the administration of a number of activities, in institutional terms the regions remain thin and fragmented and 'much of the capacity and many of the skills required to successfully operate the new architecture of regional governance are more likely to be located in Whitehall' (MARSHALL et al., 2005, p. 784). Indeed, reflecting Pierre and Peters' (2000) call for a more state-centric understanding of governance, it can be asserted that, because of its command over resources and the use of bureaucratic measures, central government has retained, or even extended its powers and control in relation to other scales of government (MUSSON et al., 2005; MARINETTO, 2003; SKELCHER, 2000). A closer examination suggests, however, that rather than the outcome of a conscious strategy, New Labour's 'rush to the regions' has been the consequence of ad hoc and largely uncoordinated actions by separate Whitehall departments aimed at improving regional economic performance and policy delivery (SANDFORD, 2005). Furthermore, although all Assemblies operate within similar policy parameters, the pattern of their activities may be more diverse than previously recognized (see for example GoOdwIN et al., 2005). Each region has its own unique socio-economic and political legacies, institutional traditions and styles of leadership and partnership working, which have shaped Assemblies' responses to decentralization.

The purpose of this article is to critically examine the evolution of Regional Assemblies within the changing context of English regionalism. It draws on documentary evidence and semi-structured interviews conducted during 2003-04 with Assembly, GO and RDA staff, representatives of the business and voluntary sectors in each region and Whitehall civil servants. We begin by briefly assessing the regional institutional legacy. Second, the Assemblies' objectives, structures and resources are examined, including an assessment of variations between regions. Third, because their effectiveness depends upon the 


\begin{abstract}
Assemblies' capacity to engage in networks, we explore channels of communication between Assemblies and central government and their participation in inter and intraregional networks. We conclude by reflecting on the achievements and constraints facing Assemblies and the factors influencing their future.
\end{abstract}

\title{
THE REGIONAL LEGACY
}

The political origins of Assemblies lie in the Labour Party's commitment to regional government made during the mid-1990s. They were not, however, created in an institutional vacuum and some regions, including the North East and West Midlands, possessed a legacy of joint local authority working (ROBERTS et al., 1999). By contrast, the East Midlands lacked a strong regional identity, while the East of England region was only established in 1994, combining the former East Anglia region with counties neighbouring Greater London. In the North West a tradition of local authority rivalry hampered efforts to secure greater regional cohesion, although agreement was eventually reached in 1992 to establish the North West Regional Association, bringing together local authorities and their regional economic and social partners (BURCH and HOLLIDAY, 1993). Similarly, during the early 1990s Yorkshire and the Humber possessed, 'A weak local authority association, which lacked a comprehensive agenda or political buy in from all the authorities or any commitment to work at regional level' (Yorkshire and Humber Assembly official). In 1997, however, recognition of the need to promote the region's economy and engage with regional partners persuaded key local authority leaders to establish England's first regional assembly capable of preparing regional land use plans, working with economic and social partners, scrutinizing the regional activities of public bodies and identifying a set of priorities around which the region's fragmented interests could be glued (YORKSHIRE AND HuMBer ASSEMBLy, 1998). 
Neither the South West nor the South East possessed a strong track record of intra-regional working. Apart from the preparation of draft RPG, the geographical size and diversity of the South West hampered joint working. Prior to 1997, the South East was the only region not to have a regional LGA, reliance being placed on sub-regional structures, while regional planning issues were dealt with by SERPLAN, whose advisory role extended beyond the region. Only when Labour's commitment to an elected Assembly for London and unelected Assemblies in English regions became tangible were the region's local authorities induced to join forces in 1997 to create the South East Regional Forum, predecessor to the current Assembly.

\section{AIMS, STRUCTURES AND RESOURCES}

\section{Key aims and objectives}

All Assemblies perform similar tasks, including:

- Advocacy on behalf of the region,

- Developing coordinated regional priorities,

- Facilitating regional debate,

- Performing a lead/partner role in the production of other strategies,

- Playing the lead role in preparing RPG/RSS,

- Providing research and intelligence,

- Scrutinizing the activities of the RDA, and

- Scrutinizing the activities of other public bodies operating in the region.

Assemblies have a 'quasi-statutory' role as RPBs, for RDA scrutiny and co-ordinating regional strategies and have sought to establish themselves as the focus for regional 
partnership working. Nonetheless, there is limited consensus about the scope or the relative importance of their activities, which reflects variations in socio-economic conditions, regional identity and political aspirations. The North East, for example, is economically and socially the most deprived of the English regions and is predominantly Labour controlled. As a consequence the region is politically cohesive and its elites have been in the vanguard of demands for new regional institutions (BENNEWORTH and TOMANEY, 2002).

By contrast, the South West region lacks a governing class committed to joint strategic decision making and the balance of political forces in the region is unsympathetic to regional government. Similarly, elected regional government has not emerged as a political project in either the South East or Eastern regions. Here, development forces are a powerful incentive for local authorities and other partners to collaborate on planning issues, but there is limited pan-regional cohesion among elites, which tend to have a fragmented, local focus and there is little enthusiasm for extending the range of activities discharged at the regional level (JoHN et al., 2002).

In the West and East Midlands tensions about the respective responsibilities of the Assemblies and the regions' Local Government Associations have been a source of uncertainty. Because it was much larger, more influential than in other regions, the West Midlands LGA had found it difficult to adjust to a more independent role for the Assembly. By contrast, the East Midlands Assembly and regional LGA merged relatively painlessly in 1999, but in 2003 parochial interests reasserted themselves and the LGA broke its formal links with the Assembly, leading to the establishment of separate chief executives and secretariats.

Despite traditional rivalries between sub-regions and local authorities, tensions between local government and the Assemblies for the North West and Yorkshire and the Humber were judged by Assembly officials to be less evident than elsewhere, easing regional 
working. Although frictions remain, institutions in both regions share a common concern about how economic forces can be managed to reduce disparities. A North West Assembly official observed that the Assembly had brought local authorities together on a more formal basis to lobby on behalf of the region. In Yorkshire and the Humber efforts have been made to manage sub-regional differences by building representation from the region's four subregions into the Assembly's political structures. Uncertainties had emerged around the respective roles of the regional LGA and the Assembly but, prompted by the Government's commitment to establish Assemblies as RPBs and assisted by Labour's dominance in the region, these were largely settled in 2001 when the region's LGA effectively handed over the 'strategic' regional agenda to the Assembly. Nonetheless, as is the case elsewhere, the recent emergence of a stronger Conservative presence has caused the Assembly to adopt a cautious approach to extending its activities.

\section{Structures}

Assemblies have adopted broadly similar constitutional and administrative structures. However, because they are expected to be representative and inclusive of their regions' interests, variations are evident (WHILE, 2000). On average each has about ninety members, comprising sixty nominated local councilors and thirty representatives of regional community interests, including business, environment groups, faith communities, trades unions and the voluntary sector (Table 1). Community representatives are expected to be selected through a fair and transparent process and be accountable to a distinct regional constituency. Compared with the number of councillors serving most English local authorities, the membership of most Assemblies is large, which reflects the need to ensure that all local authorities are represented. Yorkshire and the Humber, by contrast, has by far the smallest Assembly, only thirty-seven members, but this provides representation for each of the region's twenty-two local authorities. In some Assemblies allowance has been made 


\section{TABLE 1. ABOUT HERE}

Beneath the Executives are committees and advisory groups, described variously as 'forums', 'tasks groups', 'working groups' and 'panels', covering issues such as spatial planning and transport, RDA scrutiny, the regional economy, social inclusion and EU policies. Committees are usually made up entirely of Assembly members, while advisory groups are partnership based, including local government officers, civil servants and representatives of community interests. Assemblies also maintain links with Regional Rural Affairs Forums and Cultural Consortia. Partnerships are viewed as essential to the work of Assemblies and Table 2 illustrates those associated with the West Midlands Assembly.

\section{TABLE 2. ABOUT HERE}

Assembly structures have evolved over time; in 2003 the East of England Assembly expanded its membership from thirty-one to one hundred, a change attributed to its increased regional planning role and the English Regions White Paper. The creation of a forty-strong Executive Committee and an expansion in the number of panels reflected the view that substantive issues were not being sufficiently covered. In the East Midlands, too, 
the publication of the White Paper stimulated the Assembly to appoint the Office of Public Management to examine its structures to ensure it was fit for purpose. No change in the number of Assembly members was made but, given its slender resources, the Assembly was advised to focus on core tasks.

\section{Resources}

Initially, Assemblies were largely dependent on local authority funding but, as their responsibilities have grown, they have become more reliant on central government. In 2001 the Government announced an annual $£ 5$ million 'Chambers Fund', over three years, to support Assembly scrutiny of RDA activities and work to co-ordinate regional strategies (DETR, 2001). Each Assembly was provisionally allocated $£ 0.6 \mathrm{~m}$ per annum, with $£ 0.6$ million being allocated to joint initiatives (Table 3). The transfer of the RPB function to Assemblies was also accompanied by a one-off payment (Planning Delivery Grant), which amounted to $£ 6.2$ million in 2003-04. In addition, Assemblies are in receipt of a $£ 6$ million annual grant from the ODPM to support their on-going role as RPBs (Regional Planning Grant). The provision of resources dedicated to planning work was especially significant because, although all Assemblies had established RPG 'co-ordinating teams', they often comprised only two or three staff, usually seconded from local authorities. The new funding enabled Assemblies to expand their planning teams, promote a stronger perspective on regional priorities, reduced local government's control over the regional planning process and raised the Assemblies' regional profile. As a North West Assembly official observed, "Superficially it may be about planning, but it's also part of the Government's wider 'region building' project".

TABLE 3. ABOUT HERE 
The balance of funding reflects the Assemblies' core tasks. The West Midlands Assembly, for example, devotes about $60 \%$ of its resources to work on RPG/RSS, $35 \%$ to regional strategy coordination and 5\% to RDA scrutiny (WeSt MidLands REgionAl Assembly, 2004). Some Assemblies also receive revenues from local government training services and contributions from other regional partners to support joint research or consultation initiatives. The overall outcome is that in 2004-05 Assemblies had a joint income of some $£ 28$ million, tiny in comparison to the $£ 6.5$ billion and $£ 2.2$ billion annual funding available to the GOs and RDAs (JEFFERY and REILLY, 2004). About $60 \%$ of funding is provided by the ODPM, but in the East and West Midlands and the South East reliance on central government funding is far higher, raising concerns about the Assemblies' independence. Assemblies have limited discretion over how ODPM funding is used, there is no block grant and assistance is guaranteed for no more than two years ahead. They are also required to submit detailed business plans and claims for expenditure to the GOs, prompting resentment among some Assembly officials about the extent of 'micro-management'.

Each Assembly has an average annual income of about $£ 3.5$ million, but there are significant variations. These reflect the variable populations of regions, levels of local authority funding and the adroitness of Assemblies in taking on additional roles. The South West and North West Assemblies have annual incomes twice those of the West and East Midlands. Such comparisons are misleading, however, because of differences in the way the funding of Assemblies and their constituent regional local government bodies is managed in each region. A more accurate measure of their capacity can be gained from examining the number of staff employed in the 'core' Assembly tasks of regional planning, strategy co-ordination and RDA scrutiny. Some twenty staff are directly involved in these activities in each of the East and West Midlands Assemblies while, of the fifty or so staff employed by the South West Assembly, less than half fall within these categories. 
Similarly, of the forty or so staff employed in each of the North East, Yorkshire and Humber and East of England Assemblies, about half are engaged in these functions. The North West has by far the largest staff complement of any Assembly, more than eighty. In part this is explained by the number of staff engaged in the regional activities of local government, but this is not the whole story. The Assembly has adopted a proactive approach, including taking responsibility for the management of $\mathrm{EU}$ and national programmes, activities generally undertaken by RDAs or GOs. When these operations are discounted, the number of staff involved in core activities is not dissimilar to other regions.

Our analysis indicates that less than 200 staff are employed in core Assembly tasks. Given the range of activities expected of Assemblies this is not a large number. Indeed, Assembly officials claimed to be under constant pressure from the ODPM and other Whitehall departments to perform additional tasks and there is a strong impression that Assemblies face strategic overload. Assembly planning officials, for example, welcomed the broadening scope of the regional planning and the increased opportunities for assessing sub-regional planning frameworks. But they also expressed anxieties about the resource implications, the security of future funding streams and the difficulties of attracting suitably qualified employees. Staff constraints were also asserted to have hindered the depth of RDA scrutiny and its extension to other public bodies. As a recent report on experimental Regional Transport Boards (RTBs) concluded, while the case for giving Assemblies responsibility for RTBs is persuasive, this cannot be achieved without a strengthening of their professional and administrative support (DfT, 2004).

\section{TENSIONS WITHIN ASSEMBLIES}

As voluntary bodies with limited decision-making powers and funding, party politics do not have the same resonance in Assemblies as in local government and work is characterized as consensual. Nonetheless, suggestions that disagreements on party political, sectoral or 
territorial lines have been suspended would be misleading. There are clear differences between the political parties over the role of Assemblies, as well as distinct territorial differences of interest. Indeed, despite Government guidance on the need for Assemblies to take tough decisions on strategic planning issues, there is a tendency for local authority representatives to focus on local rather than regional priorities, inhibiting Assemblies from reaching a concerted view. Moreover, because of their perceived remoteness and the weight of urban interests in regional politics, there is evidence of mistrust among rural interests to Assemblies (PEARCE et al., 2005).

The participation of economic and social partners in Assemblies, alongside local authority representatives, is seen as an opportunity to harness the energies, skills and resources of individuals with valuable experience and encourage them to 'buy into' policies at an early stage. Assemblies, therefore, provide a forum for regional partners, often with very different perspectives, to develop a dialogue and search for mutually beneficial solutions to shared problems through building and sustaining trust. A South West voluntary sector Assembly member remarked, 'We've been forced together in various task groups and meetings and that's helped them [local authority representatives] to understand the contributions we can make to the agenda'. The stress on partnership working has also prompted various groupings of economic and social partners, especially the business and voluntary sectors, to strengthen existing or establish their own regional organizations. In theory, the outcome should be more refined decision making and greater commitment to delivery. Assembly decisions, however, are not binding on any individual member and, although policies may be supported at regional level, agreements may quickly unravel when it comes to their implementation.

Some partners, particularly business representatives, clearly view Assembly processes as irksome and several Assembly officials expressed concerns about the difficulties of 
attracting and retaining business leaders with the necessary skills. Moreover, voluntary and community sector engagement in regional partnership working is widely seen to be hampered by lack of funding. Conversely, non-local authority partners were sometimes seen to have unrealistic expectations in terms of their influence and, although relationships had improved, local authority representatives were not always sympathetic to their presence. Some authorities, for example, had resisted the assignment of voting rights on regional planning matters to unelected Assembly members. A West Midlands Assembly official observed, 'The name of the game is partnership working, inclusivity and taking account of business interests. But, there are many councillors who don't accept that. Nor do they accept that other stakeholders have a legitimate voice'.

GO and RDA officials confirmed this view, but some went further. They expressed satisfaction with the competencies of the majority of social and economic partners, but were critical of the quality of some local authority representatives. Furthermore, local authority Assembly members with experience of regional working, gained through involvement in the metropolitan counties during the 1980s, were reaching the end of their political careers and their replacements were seen to have grown up in political traditions focused on localities.

'I can't see many people coming through with the same sort of vision and authority.

The political system throws up leaders of sorts and we have to try and feed them their lines to provide regional leadership' (Assembly official).

\section{EXTERNAL NETWORKS}

\section{Relations with central government}

Whitehall's perspective on the role of regions has evolved over recent years. Evidence for this lies in the adoption of a long-term target to reduce the persistent gap in economic 
growth rates between regions, pressures on departments to engage in cross cutting policy issues with a regional dimension and the introduction of a regional dimension to the spending review process. At the regional level RDAs have been granted remarkable access to ministers and GO staff have links with their Whitehall counterparts across a wide range of departments. By contrast, apart from meetings between ODPM junior ministers and Assembly leaders and ODPM and DfT civil servants and Assembly staff engaged in planning and transport policy work, direct links between Whitehall departments and Assemblies are infrequent (AYRES and PEARCE, 2004a; MAWSON and SNAPE, 2004). Government rhetoric might stress the merits of engaging regional and local bodies in national policy making but there was limited evidence that this extended to Assemblies. 'In terms of what it feels like out here on the ground, I have to say that the impact has been fairly limited, except in a small number of cases or areas, most of which are in ODPM' (Yorkshire and Humber Assembly official).

Ostensibly, regional institutions are being encouraged to generate regional solutions and apply greater discretion over policy implementation. However, nationally determined targets and departmental funding streams remain persuasive. The Sustainable Communities Plan, for example, proposes major urban growth in parts of south east England, but the South East and East of England Assemblies have both asserted that this cannot be achieved without a step change in government funding for affordable housing, social and transport infrastructure and measures to mitigate the environmental impacts of urban growth (EAST of England Assembly, 2004; South East Assembly, 2004, ODPM, 2002). An East of England Assembly official asserted that 'over time Whitehall has begun to get the message and in our lobbying we can see how briefings for ministers are changing'. Nonetheless, though additional resources and some realignment of policy can be anticipated, there is little prospect of the Assemblies diverting the Government from its housing growth targets. 
The ODPM's proposal in 2003 to create independent Regional Housing Boards, separate from Assemblies' planning functions, was widely rebuked by Assembly officials. Subsequently, the decision was reversed and, in recognition of the need to tie housing more closely to RSSs, Assemblies have been charged with preparing Regional Housing Strategies (RHAs) (ODPM, 2004b). Regional Rural Affairs Forums and Regional Cultural Consortia were also regarded as anomalies because they report to ministers, rather than Assemblies. Several Assembly officials commented ruefully on the unpredictability of Whitehall's regional initiatives,

'We never know what reaction we're going to get', ... 'Not only are departments different but there are different levels of understanding within them', ... 'The DfES and DoH have largely bypassed the regional tier in favour of sub-regional structures. DTI is tokenistic and when it thinks about regions it thinks of RDAs', .. 'DEFRA, after a late start, is beginning to get a regional perspective into its work.'

Assembly officials regarded the Treasury's growing interest in incorporating a regional dimension into spending reviews, improving knowledge about regional public expenditure and adopting regional targets, as one of the more unexpected features of the evolving regional agenda. They welcomed the Treasury's invitation to Assemblies, GOs and RDAs to jointly prepare Regional Emphasis Documents to inform the 2004 spending round, but were sceptical about their influence and the extent to which Whitehall's regional targets could be aligned with regional priorities (HM TREASURY, 2003).

A further measure of Whitehall's growing awareness of Assemblies is the marked increase in the incidence of consultation.

'It comes through in all sorts of ways and feels like a rapidly expanding and developing agenda, as more and more government departments are developing awareness of the 
potential of the regional tier. Where we have a legitimate interest there are opportunities for influence' (South East Assembly official).

Similarly, the English Regions White Paper was seen as an important 'psychological step' in signalling to government bodies operating in the regions, such as the Environment and Highways Agencies, the need for increased dialogue with Assemblies and for greater weight to be given to regional priorities. In practice, however, the principle task of these institutions remains the achievement of programme targets set by sponsor departments and accountability mechanisms discourage territorial flexibility.

\section{Working with other regions}

Historically, limited attention has been given to planning issues that cut across regional boundaries, but the ODPM has urged Assemblies to consult with neighbouring regions when preparing their planning strategies. The most conspicuous example of inter-regional working is in south east England, where bodies in Greater London and the East of England, East Midlands and South East regions are collaborating to implement the Sustainable Communities Plan. Elsewhere, the RDAs in the three northern regions are leading on the 'Northern Way', a cross-regional approach aimed at supporting investment priorities in the north's eight city regions (NORTHERN WAY STEERING GROUP, 2004). Similarly, under the 'Midlands Way', the East and West Midlands' RDAs, together with their key regional partners, are discussing joint responses to the challenges of the Sustainable Communities Plan and national productivity drivers (Advantage WeSt MidLANDS and EAST MidLANDS DEVElOPMENT AGENCY, 2005).

Other examples of cross border working, directly involving Assemblies, tend to focus almost exclusively on staff contacts over planning issues. Indeed, officials confirmed the difficulties involved in securing regular political links between Assemblies and shared 
positions on policy issues. Where inter-regional collaboration had occurred, it had more often been the outcome of EU or national initiatives, rather than a 'bottom-up' response from neighbouring regions. To facilitate joint working between Assemblies and strengthen the regions' voice in central government the English Regions Network (ERN) was established in 2001, part funded by the ODPM. Views on the Network's effectiveness varied. Several Assembly officials judged it well placed to lobby the ODPM on planning issues, but were critical of its abilities to engage with other Whitehall departments. Others expressed a desire to match the RDAs' capacity to orchestrate a concerted approach on major policy issues to ministers, but differences between Assemblies over priority issues had hindered agreements. Given such sentiments, this Assembly official's view on the ERN was not unexpected,

'It's amateurish, members won't go to meetings any more, they're not interested. It's easier to get social and economic partners to ERN meetings than local authority representatives. If we want recognition we need to do something better than this'.

Many Assemblies have links with regions in other European states and all contribute to the funding of regional offices in Brussels (BURCH and GOMEZ, 2002). By contrast, contacts between Assemblies and institutions in the UK's devolved territories are infrequent. We were advised that the North West Assembly had engaged with the Welsh Assembly and neighbouring Welsh local authorities on a cross border sub-regional planning study. Similarly, planning staff in the West Midlands Assembly and their counterparts in Wales have exchanged views on the RSS and the Welsh Spatial Plan. However, officials from the North East and North West Assemblies described their contacts with the Scottish Executive as 'virtually nil' and 'difficult, they' re not interested'. 
The regional tier has emerged as a venue for the preparation of a proliferation of regional strategies, often promoted by Whitehall departments, including economic development, energy, health, housing, land use, sustainable development and transport. Nonetheless, a lack of co-ordination of the various strategy processes and uncertainties over responsibilities for the implementation of associated policy actions have often inhibited their delivery. Indeed, while institutions may be bound by a common desire to improve regional conditions, each is influenced by different agendas and accountabilities.

Despite these constraints, the Government expects the relationship within the troika to be one of partnership and co-operative working (REGIONAL CO-ORDINATION UNIT, 2003). Collaboration is clearly essential in managing the complexities of regional working and developing a shared understanding of regional priorities and considerable efforts have been made to foster dialogue between key agencies. As an RDA Chief Executive observed,

'We promise to be nice to each other, as not to do so would have some negative consequences for the region. By relating together we can learn to trust one another and do things better. It doesn't mean that it's all sweetness and light. Life is about politics and tensions, but we're working towards the same objective at the end of the day - a successful region'.

Because they are intended to cover not only traditional land use issues, but also the spatial aspects of a range of policies, including health, skills and social exclusion, the new RSSs are seen to have scope for co-ordinating policies and resources to fulfil both national and regional priorities. As a consequence, Assemblies have come under growing pressures from the ODPM to identify the level of public investment required to implement their RSSs, which has also given rise to demands from Assemblies for greater transparency in the 
spatial distribution of public expenditure. There remains, however, an important distinction between the capacity of Assemblies to both draft and implement RSSs. In practice, RSSs are issued by the Government's Regional Offices and their delivery is largely dependent upon Whitehall's spending plans, which may not match regional priorities. Indeed, despite their statutory status, Assembly staff remain circumspect about the potential of RSSs to redirect resources to meet regional priorities.

The English Regions White Paper also stressed that Assemblies should play the lead role in coordinating strategies to deliver sustainable development, while GOs were charged with the complementary task of supporting Assemblies in their strategy alignment role, by cocoordinating the activities of public bodies in the regions and encouraging them to incorporate a regional dimension in their activities. The task is challenging; in the West Midlands, for example, there are more than thirty regional strategies and sub-strategies at various stages of preparation, containing over six-hundred 'aims' 'objectives', 'policies', 'priorities' and 'targets' (AyRES and PEARCE, 2004b). Moreover, because the White Paper allotted responsibility for regional coordination to both GOs and Assemblies, some Assembly officials expressed uncertainty about how far they might encroach on the GOs' role by entering into a dialogue and seeking to influence the extensive range of public bodies operating in the regions. More generally, despite GO claims that they participate as 'equal partners', Assembly staff were critical of the capacity of GO officials to formulate advice without reference to Whitehall and their ability to combine working with Assemblies to prepare RSSs with their quasi-judicial role in examining and issuing the strategies on behalf of the ODPM.

All Assemblies have made progress in scrutinizing the RDAs' plans and activities, including links with other strategies, though 'less has been achieved in terms of Assemblies being able to point to concrete impact and added value' (SNAPE et al., 2003, p. 103). In 
some regions, the scrutiny process prompted considerable hostility between Assemblies and RDAs over their respective roles and status and the parity of esteem afforded to the 'economic' focus of the RESs and the 'environmental' and 'social' considerations in RPG. According to Assembly officials, however, the introduction in 2002 of dedicated funding for Assemblies to scrutinize RDAs in a more professional manner, learning through 'trial and error' and a desire to avoid deadlock and damaging public disagreements, had helped ease tensions. Senior GO and RDA officials also confirmed that increased dialogue had improved Assembly-RDA relations, but were less sanguine about their Assemblies' effectiveness in challenging or holding RDAs to account for their strategies, diminishing scrutiny as a policy development tool.

To facilitate regional co-ordination several Assemblies have signed 'Concordats' with GOs, RDAs and other bodies, including the Environment Agency and Learning and Skills Councils, setting out respective roles and responsibilities. Views about the value of Concordats were not, however, always flattering. The majority of GO and RDA officials interviewed were dismissive while even some Assembly officials acknowledged that, because regional functions are constantly expanding, Concordats quickly become out of date. Officials in some Assemblies also stressed the value of their region's Sustainability Development Framework (SDF) as a high level statement of the region's vision, which provided a policy thread running through all regional strategies. Nonetheless, because sustainable development is a less than 'clear-cut, stand-alone concept', there was uncertainty about how the term should be defined and applied (HAUGHTON and COUNSELL, 2004, p. 26). As an Assembly official acknowledged, 'It's been at the core of our vision since the late 1990s, though then we didn't really understand what it was or how to achieve it'. 
In responding to the aspiration that all public bodies operating in the regions 'join up' their policies, several Assemblies have adopted, or are in the process of preparing, 'Integrated Regional Strategies' (IRSs). The process has been given added impetus by the commitment to greater regional strategy co-ordination made in the 2004 Spending Review (HM TREASURY, 2004). Their value is seen to lie in establishing a regional consensus around a clear set of overarching principles or priorities, which provide the context for the development of regional strategies. They should also assist in identifying potential conflicts between objectives and priorities and indicate how these might be mitigated.

The East Midlands is further along this route than other Assemblies. It began with an overall regional vision and a set of eighteen economic, social, environmental and spatial 'sustainable development' objectives. These would provide the template for assessing how policies contribute to the region's wider objectives. In addition to promoting horizontal integration, the IRS model also stresses the role of sub-regional actors in delivering regional priorities. Progress has been documented against indicators in various policy areas and work is continuing to identify the key actions and actors required to deliver the strategy (East Midlands Regional Assembly, 2005). Assembly officials suggested that the IRS had improved regional decision-making through more joint working between organizations, a shared understanding of regional issues and priorities and a clear statement of objectives and outcomes. They also judged that the approach has the potential to achieve a more effective allocation of resources by providing a coherent message about the region's needs, both in Whitehall and to government bodies working in the region.

With regional partners the South West Assembly has also developed an IRS, Just Connect, which sets out regional priorities and issues and aims to inform the activities of regional partners. (South West Regional Assembly, 2004). Similarly, the Yorkshire and Humber Assembly and its partners have relaunched the 1998 strategic framework, Advancing 


\section{Together (YORKSHIRE AND HUMBER ASSEMBLY, 2004). 'It's not a strategy but a strategic} framework, a high level vision containing agreed objectives for the region and with benchmarks to assess progress' (Yorkshire and Humber official). Joint sustainability appraisals, set in the context of the region's SDF, are being applied to achieve greater consistency between RPG, the RES and regional housing strategy and arrangements have been put in place to co-ordinate the preparation of the RSS with reviews of the region's economic and housing strategies.

Despite the outward attractions of an IRS, or similar document, they are no guarantee of policy integration and a major challenge for Assemblies is to ensure that agreements on regional priorities between regional stakeholders are followed through. The East Midlands Assembly, for example, is seeking to extend the IRS to the co-ordination of delivery. But, as an Assembly official acknowledged,

'When we start to raise the issue, the relationship between the region and its subregions comes into play and it's difficult to convey the links to those engaged in delivery. In relation to planning there is a neat set of tiers in which the Assembly plays a key role, but not in other policy areas.'

Not all Assemblies have been enthusiastic about the need for a documented IRS. Although having broad agreement on regional priorities is vital, creating regional 'meta' strategies can be regarded as unrealistic, demanding in resource terms and introducing an unnecessary degree of rigidity; 'An IRS is not the right way to proceed. The critical thing is to have the regional strategy/plan making process in place and develop the networks for delivering' (North West Assembly official). West Midlands Assembly officials maintained that the regional Concordat already provided a framework for strategy co-ordination by setting out the responsibilities of the key regional bodies and were resistant to the need for an IRS. The 
practicality of delivering a joined up approach to delivery was seen to lie in constantly making connections between strategies to determine how one impacts on the other.

'We don't need another regional strategy. We need to have principles and these can be used as the conscience of the region. We know we need to ensure that strategies are aligned, but let's do that in a bottom up way through an implementation framework. You can best achieve integration by working at the practical end, the sub-regional level where resources come together' (West Midlands Assembly official).

Similar sentiments were shared by several GO and RDA officials. They viewed the IRS model as a distraction and offering limited added value to delivery. As a GO Regional Director observed, 'In terms of [regional] co-ordination, the Regional Housing Boards are far more influential in tying in the RES, RPG and environmental sustainability. They're involved in all the elements, which will lead to something on the ground'.

\section{CONCLUSION}

This account provides a number of important insights into the Assemblies' activities in the context of broader developments in English regional governance. It underlines that since their inception Assemblies have fostered networking and collaboration between regional stakeholders, assisted in the development and co-ordination of a range of regional policies and played a constructive role in working with GOs and RDAs to influence and monitor the achievement of collective regional goals. Moreover, in their capacity as Regional Planning Bodies, responsible for the new statutory RSSs, Assemblies have become increasingly engaged in coordinating land use, transport, housing and other policy areas and linking regional and sub-regional working. The Government is committed to transferring strategic responsibilities for regional housing and transport to Assemblies and, alongside their troika partners, Assemblies have recently engaged in preparing advice to ministers on regional 
priorities within a framework of indicative long-term regional funding, covering housing, economic development and transport (HM TREASURY et al, 2005). Each of these activities has assisted Assemblies in raising their profiles among regional stakeholders and can be viewed as indicative of a broader process involving the rescaling of the institutions responsible for policy formulation and implementation both vertically, between different level of governance, and horizontally, between institutions serving the same regions.

Despite these achievements the limited executive powers available to Assemblies have given rise to tensions and ambiguities over their responsibilities. Uncertainties have arisen over the respective roles of Assemblies, RDAs GOs and other public bodies operating in the regions and the status of individual strategies. Moreover, while Assemblies are formally committed to engage a broad range of stakeholders, difficulties have occurred in balancing fragmented interests and promoting greater regional awareness and vision. Furthermore, although some Assemblies have been keen to establish Concordats with key regional partners and prepare Integrated Regional Strategies, there is disagreement and lack of evidence about the value of such arrangements in securing improved policy coordination and outcomes.

Within these overall trends Assemblies have followed different trajectories, which reflect diverse regional institutional inheritances and economic and social geographies. In the South East of England, for example, the key policy challenge is to manage the problems of economic success, while the main concern underpinning policy for the northern regions is to boost their economic performance. Regional political differences have also played their part in shaping Assembly priorities; while the Conservative dominated Eastern and SouthEast Assemblies have eschewed political devolution, in the North-East the drive to elected regional government was, until recently, an overriding concern. Similarly, the presence of 
forceful local authority associations in some regions has influenced the scope of Assembly activities.

Intra-regional factors have, therefore, played a part in determining the Assembly agendas. However, there is no strong sense of any Assembly pressing hard to extend its current range of activities. Indeed, rather than having the capacity to absorb additional responsibilities, there are doubts about the Assemblies' competencies to cover their existing tasks. Far more significant in shaping the Assemblies' activities has been central government. Given the lack of public support for elected regional bodies and ambiguities arising from the centre's preference to develop regional structures alongside and, in part, overlapping established central-local policy relationships, Whitehall departments have been able to adopt a piecemeal approach. Indeed, along with a wider assessment of the roles and capacities of respective government tiers and institutions, there is a need to take stock of what tasks Assemblies should perform, and why, and the resources required for their delivery. Fundamentally, Assemblies are viewed in Whitehall as minor institutions compared with the GOs and RDAs, which has constrained them from adopting a more holistic, bottomapproach to policy making. Consequently, while Assemblies may work diligently to build partnerships, formulate regional solutions and draw on the 'know how' of regional stakeholders, a lack of political legitimacy and financial resources fetters them from forging authoritative regional perspectives and exerting influence over the activities of key public bodies serving the regions.

Following the result of the North East referendum in 2004 plans to democratize English regional governance were quietly withdrawn. There are already demands from local authorities for the Assemblies' accountability and coordination functions to be dismantled and for responsibility for regional spatial planning to return to local government. There are also calls for the creation of 'city regions', comprising partnerships between local 
authorities serving the major provincial cities and their hinterlands, with the financial and political muscle necessary to improve their territories' economic performance (MARSHALL AND FINCH 2006; NEW LOCAL GOVERNMENT NETWORK. 2005). Nonetheless, the structures of regional governance and the interlocking policy issues associated with regional economies, housing, spatial planning and transport remain. Local authorities are unable to tackle these strategic needs and, as Hazell (2006, p. 49) asserts, 'city regions are essentially technocratic, of interest to élites not ordinary people, and at best a patchwork solution'. It would also be a retrograde step for RDAs or GOs to be granted additional powers and resources without a guarantee of supervision by elected representatives and their non-local authority partners. As Bradbury and Mitchell (2005, p. 300) claim,

'Stakeholder Assemblies, RDAs and GOs have become the principal building blocks of developing government in the regions since 1997' and, so long as 'John Prescott remains a powerful figure in government, it is likely that the powers of the non-elected Assemblies will be bolstered'.

Whether these will be sufficient, however, to enable Assemblies to develop their capacities and augment their popularity to deliver a narrow 'yes' in some future referendum remains doubtful. Indeed, given the public's antipathy to state restructuring and local government's dislike of elected regional government, ministers and civil servants will continue to pursue regional working in those policy areas where there is the least threat to the centre. In these circumstances the prospects of Assemblies accumulating powers and resources similar to those enjoyed by the UK's devolved institutions, appear distant.

Acknowledgements: The authors would like to thank two referees for their very helpful comments and suggestions. The article is based upon research into 'Emerging patterns of governance in the English regions' funded through the Economic and Social Research Council's Devolution and Constitutional Change Programme (Project No. L21952113). It 
draws on interviews with officials in each Regional Assembly, Government Regional Office, Regional Development Agency, representatives of regional business and voluntary interests and Whitehall officials. All interviews were undertaken under Chatham House Rules.

\section{REFERENCES}

ADVANTAGE WEST MIDLANDS and EAST MIDLANDS DEVELOPMENT AGENCY (2005) Smart Growth the Midlands Way. Consultation Document. East Midlands Development Agency, Nottingham.

AYRES S. and PEARCE G. (2004a) Central government responses to governance change in the English regions, Journal of Regional and Federal Studies 14, 255-281.

AYRES S. and PEARCE G. (2004b) Rural strategies, frameworks and policies. West Midlands Regional Assembly, Birmingham.

BACHE I. and FLINDERS M. (2004) Multi-level governance and British politics, in BACHE, I. and FLINDERS, M. (Eds.) Multi-level governance, pp. 93-106. Oxford University Press, Oxford.

BENNEWORTH P. and TOMANEY J. (2002) Regionalism in North East England, in TOMANEY, J. and MAWSON, J. (Eds.) England: the State of the Regions, pp. 137-146. Policy Press, Bristol.

BOGNADOR V. (Ed.) (2005) Joined-up government. Oxford University Press, Oxford. BRADBURY J and MITCHELL J. (2005) Devolution: Between governance and territorial politics, Parliamentary Affairs 58, 287-302. 
BURCH M. and GOMEZ R. (2002) The English regions and European initiatives.

Devolution and European Union Policy Making Series, Paper No. 4, Department of

Government, University of Manchester, Manchester.

BURCH M. and HOLLIDAY I. (1993) Institutional emergence: The case of the North West region of England, Regional Policy and Politics 3, 29-50.

CABINET OFFICE and DEPARTMENT FOR TRANSPORT, LOCAL GOVERNMENT AND THE REGIONS (2002) Your region, your choice: Revitalizing the English regions. Stationery Office, London.

DEPARTMENT FOR TRANSPORT (2004) Evaluation of experimental Regional Transport Boards. Department for Transport, London.

DEPARTMENT FOR TRANSPORT, LOCAL GOVERNMENT AND THE REGIONS (2001) Planning: Delivering a fundamental change. Department for Transport, Local Government and the Regions, London.

DEPARTMENT OF THE ENVIRONMENT, TRANSPORT AND THE REGIONS (2001) Strengthening regional accountability: Consultation paper. Department of the Environment, Transport and the Regions, London.

EAST MIDLANDS REGIONAL ASSEMBLY (2005) England's East Midlands Integrated Regional Strategy: Our Sustainable Development Framework. East Midlands Regional Assembly, Melton Mowbray.

EAST OF ENGLAND REGIONAL ASSEMBLY (2004) The East of England Plan: Draft Regional Spatial Strategy for the East of England. Regional Planning Panel and Secretariat, $5^{\text {th }}$ November, Eastern Regional Assembly, Bury St Edmunds. 
GOODWIN M., JONES M. and JONES R. (2005) Devolution, constitutional change and economic development: Explaining and understanding the new institutional geographies of the British state, Regional Studies 39, 421-436.

HAUGHTON G. and COUNSELL D. (2004) Regions, spatial strategies and sustainable development. Routledge, London.

HAZELL R. (2006) The English Question, Publius 36, 37-56.

HM TREASURY (2003) Spending review 2004: Regional Emphasis Documents. Letter to Government Regional Offices, Regional Development Agencies and Regional Assemblies, HM Treasury, London.

HM TREASURY (2004) 2004 Spending review: Meeting regional priorities. Stationery Office, London

HM TREASURY, DEPARTMENT FOR TRANSPORT, DEPARTMENT OF TRADE AND INDUSTRY and OFFICE OF THE DEPUTY PRIME MINISTER (2005) Regional funding allocations: Guidance on preparing advice. Stationery Office, London.

JEFFERY C. (2006) Devolution and local government, Publius 36, 57-73.

JEFFERY C. and REILLY A. (2004) Funding Regional Assemblies: Issues and challenges. Report for the English Regions Network, University of Birmingham, Birmingham.

JOHN P., MUSSON S. and TICKELL A. (2002) 'England's problem region: Regionalism in the South East', Regional Studies 36, 733-741.

MARINETTO M. (2003) Governing beyond the centre: A critique of the AngloGovernance School, Political Studies 51, 592-608.

MARSHALL A. and FINCH D. (2006) City leadership: Giving city-regions the power to grow. Institute of Public Policy Research, London. 


\begin{abstract}
MARSHALL J., BRADLEY D., HODGSON C. and RICHARDSON R. (2005) Relocation, relocation, relocation: Assessing the case for public sector dispersal, Regional Studies 39, 767-787.
\end{abstract}

MAWSON J. and SNAPE S. (2004) The Chapter 2 agenda and Regional Assemblies, Part II: The Whitehall View. Institute of Governance and Public Management, Warwick University, Coventry.

MUSSON S. TICKELL A. and JOHN P. (2005) A decade of decentralization? Assessing the role of the Government Offices for the English regions, Environment and Planning A $37,1395-1412$.

NEW LOCAL GOVERNMENT NETWORK (2005) Seeing the Light. New Local Government Network, London.

NORTHERN WAY STEERING GROUP (2004) Moving forward: The Northern Way: First growth strategy report sustainable communities. One North East, Newcastle on Tyne.

OFFICE OF THE DEPUTY PRIME MINISTER (2002) Sustainable Communities: Delivering through Planning. Office of the Deputy Prime Minister, London.

OFFICE OF THE DEPUTY PRIME MINISTER (2004a) Planning Policy Statement 11: Regional Spatial Strategies. Office of the Deputy Prime Minister, London.

OFFICE OF THE DEPUTY PRIME MINISTER. (2004b) Housing and planning in the regions. Office of the Deputy Prime Minister, London.

PEARCE G., AYRES, S. and TRICKER M. (2005) Decentralization and devolution to the English regions: Assessing the implications for rural policy and delivery, Journal of Rural Studies 21, 197-212.

PIERRE J. and PETERS G. (2000) Governance, politics and the state. Macmillan, London. 
REGIONAL CO-ORDINATION UNIT (2003) 2002-3 Report on the work of the Government Offices for the Regions. Office of the Deputy Prime Minister, London.

RHODES R. A. W. (1997) Understanding governance: policy networks, governance and accountability. Open University Press, Buckingham.

ROBERTS P., THOMAS K. and WILLIAMS G. (1999) Metropolitan planning in Britain: A comparative study. Jessica Kingsley Publishers, London.

SANDFORD M. (2005) Devolution is a process not a policy: The new governance of the English regions. Briefing No 18, Economic and Social Research Council, Devolution and Constitutional Change Programme, Edinburgh.

SKELCHER C. (2000) Changing images of the state: overloaded, hollowed-out and congested, Public Policy and Administration 15, 3-19.

SNAPE S., ASHWORTH R. AULAKH S. DOBBS L. and MOORE C. (2003) The development of regional scrutiny: Final report, Institute of Governance and Public Management, Warwick University, Coventry.

SOUTH EAST REGIONAL ASSEMBLY (2004) Report of the Chairman of the Regional Planning Committee. 29 November, South East Regional Assembly, Guildford.

SOUTH WEST REGIONAL ASSEMBLY (2004) Just Connect. South West Regional Assembly, Taunton.

WEST MIDLANDS REGIONAL ASSEMBLY (2004) West Midlands Regional Assembly Business Plan, 2004-06. West Midlands Regional Assembly, Birmingham.

WHILE A. (2000) Accountability, and regional governance: The emerging role of regional chambers in England, Local Economy 14, 329-345. 
YORKSHIRE AND HUMBER REGIONAL ASSEMBLY (1998) Yorkshire and

Humberside: Advancing together into the millenium: A strategic framework. Yorkshire and Humber Regional Assembly, Wakefield.

YORKSHIRE AND HUMBER REGIONAL ASSEMBLY (2004) Advancing together. Yorkshire and Humber Regional Assembly, Wakefield.

28.2.06 
Table 1. Regional Assemblies: Membership categories, 2004

\begin{tabular}{|c|c|c|c|c|c|c|}
\hline Region & $\begin{array}{l}\text { Population } \\
\text { (million) }\end{array}$ & $\begin{array}{c}\text { Number of } \\
\text { local } \\
\text { authorities }\end{array}$ & $\begin{array}{c}\text { Total } \\
\text { Assembly } \\
\text { membership }\end{array}$ & $\begin{array}{l}\text { Local } \\
\text { authority } \\
\text { members }\end{array}$ & $\begin{array}{c}\text { Economic and } \\
\text { social partner } \\
\text { members }\end{array}$ & Others \\
\hline $\begin{array}{l}\text { East of } \\
\text { England } \\
\text { East }\end{array}$ & 5.4 & 54 & 107 & 75 & 32 & \\
\hline Midlands & 4.2 & 46 & 111 & 70 & 35 & $\begin{array}{l}\text { Six MEPs } \\
\text { One MP, one } \\
\text { MEP and one } \\
\text { representative of } \\
\text { parish/ town }\end{array}$ \\
\hline $\begin{array}{l}\text { North East } \\
\text { North }\end{array}$ & 2.5 & 25 & 72 & 47 & 22 & councils \\
\hline West & 6.9 & 46 & 80 & 56 & 24 & $\begin{array}{l}\text { Three } \\
\text { representatives } \\
\text { of parish/town }\end{array}$ \\
\hline South East & 8.1 & 74 & 111 & 74 & 34 & $\begin{array}{l}\text { councils } \\
\text { Two National } \\
\text { Park } \\
\text { representatives } \\
\text { and two } \\
\text { representatives } \\
\text { of parish/town }\end{array}$ \\
\hline $\begin{array}{l}\text { West } \\
\text { West }\end{array}$ & 4.9 & 51 & 117 & 79 & 34 & councils \\
\hline $\begin{array}{l}\text { Midlands } \\
\text { Yorkshire/ }\end{array}$ & 5.2 & 38 & 100 & 68 & 32 & \\
\hline Humber & 5.0 & 22 & 37 & 22 & 15 & \\
\hline Totals & 42.2 & 356 & 735 & 491 & 228 & 16 \\
\hline Averages & 5.3 & 44.5 & 91.9 & 61.4 & 28.5 & 2.0 \\
\hline
\end{tabular}


Planning Partnership - Assembly \& West Midlands Local Government Association funded. Planning Executive - Assembly funded.

Transport Partnership - Assembly \& West Midlands RDA funded.

Housing Partnership - Assembly \& West Midlands Local Government Association funded. European and International Partnership - Assembly \& West Midlands RDA funded.

Cultural Partnership (Regional Cultural Consortium) - DCMS funded.

Rural Partnership (Regional Rural Affairs Forum) - Assembly \& DEFRA funded.

Health Partnership - Assembly \& GO funded.

Environment Partnership - Assembly \& Environment Agency funded.

Social Inclusion Partnership - Assembly funded.

Regional Skills Partnership - West Midlands RDA \& DfES funded.

Source: West Midlands Regional Assembly, 2004 
Table 3. Regional Assemblies income 2004-05 (£ million)

\begin{tabular}{|c|c|c|c|c|c|c|c|c|}
\hline Region & $\begin{array}{c}\text { Total } \\
\text { income }^{1}\end{array}$ & $\begin{array}{l}\text { Total } \\
\text { ODPM } \\
\text { income }^{2}\end{array}$ & $\begin{array}{c}\text { Planning } \\
\text { Delivery } \\
\text { Grant }\end{array}$ & $\begin{array}{c}\text { Chamber } \\
\text { Fund }\end{array}$ & $\begin{array}{c}\text { Regional } \\
\text { Planning } \\
\text { Grant }\end{array}$ & Subscriptions $^{3}$ & Other & $\begin{array}{c}\text { Source of } \\
\text { subscription, } \\
\text { other income }\end{array}$ \\
\hline $\begin{array}{l}\text { East of } \\
\text { England } \\
\text { East }\end{array}$ & 3.0 & 1.9 & 0.5 & 0.6 & 0.8 & 1.1 & $<0.1$ & $\begin{array}{l}\text { Local } \\
\text { authorities and } \\
\text { other partners }\end{array}$ \\
\hline $\begin{array}{l}\text { Midlands } \\
\text { North }\end{array}$ & 2.1 & 2.1 & 0.8 & 0.6 & 0.7 & Nil & $<0.1$ & $\begin{array}{l}\text { Nil } \\
\text { Local }\end{array}$ \\
\hline $\begin{array}{l}\text { East } \\
\text { North }\end{array}$ & 3.5 & 1.4 & 0.3 & 0.6 & 0.5 & 0.9 & 1.2 & $\begin{array}{l}\text { authorities } \\
\text { Local }\end{array}$ \\
\hline West & 4.6 & 2.6 & 1.1 & 0.6 & 0.9 & 0.6 & 1.4 & $\begin{array}{l}\text { authorities, } \\
\text { EU }\end{array}$ \\
\hline $\begin{array}{l}\text { South } \\
\text { East }\end{array}$ & 4.0 & 3.3 & 1.7 & 0.6 & 1.0 & 0.7 & $<0.1$ & $\begin{array}{l}\text { Local } \\
\text { authorities }\end{array}$ \\
\hline South & & & & & & & & $\begin{array}{l}\text { Local } \\
\text { authorities, } \\
\text { Trade Union, } \\
\text { course and } \\
\text { consultancy }\end{array}$ \\
\hline West & 4.8 & 2.1 & 0.7 & 0.6 & 0.9 & 0.7 & 2.0 & $\begin{array}{l}\text { fees } \\
\text { Local } \\
\text { authorities, } \\
\text { RDA, ERN, } \\
\text { Sustainability } \\
\text { West }\end{array}$ \\
\hline $\begin{array}{l}\text { Midlands } \\
\text { Yorkshire/ }\end{array}$ & 2.4 & 2.1 & 0.7 & 0.6 & 0.7 & 0.3 & $<0.1$ & $\begin{array}{l}\text { Midlands } \\
\text { Local }\end{array}$ \\
\hline Humber & 4.0 & 1.9 & 0.6 & 0.6 & 0.7 & 1.5 & 0.6 & authorities \\
\hline Totals & 28.4 & 17.4 & 6.4 & 4.8 & 6.2 & 5.8 & 5.2 & \\
\hline
\end{tabular}

Based on Jeffery and Reilly, 2004

Notes: 1. Total income is made up of ODPM income plus all other income.

2. Total of Chambers Fund, Regional Planning Grant and Planning Delivery Grant.

3. Subscriptions from local authorities and grants from national bodies and other partners.

4. Other income includes revenue from training enterprises, interest from investments, consultant fees, publications and transfers from other regional bodies. 